\title{
Sarkofagus Ampelan Wringin: Data Baru Tradisi Megalitik Di Bondowoso
}

\section{Diman Suryanto}

Keywords: megalithic, typology, chronology, description, indonesia

\section{How to Cite:}

Suryanto, D. (2004). Sarkofagus Ampelan Wringin: Data Baru Tradisi Megalitik Di Bondowoso. $\quad$ Berkala 29-37. https://doi.org/10.30883/jba.v24i1.891

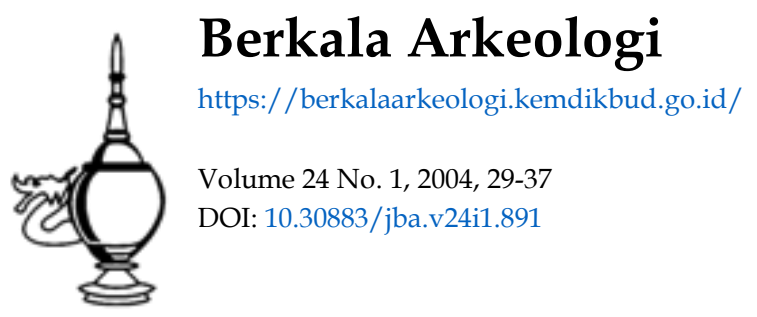

\section{c) (i) (2)}

This work is licensed under a Creative Commons Attribution-NonCommercial-ShareAlike 4.0 International License. 


\title{
SARKOFAGUS AMPELAN WRINGIN: DATA BARU TRADISI MEGALITIK DI BONDOWOSO
}

\author{
Diman Suryanto
}

$\mathbf{P}$ endahuluan

Sarkofagus, adalah kubur batu yang terdiri dari wadah dan tutup banyak ditemukan di Bali dan Jawa Timur (Bondowoso). yang pada ujung-ujungnya terdapat tonjolan. Masyarakat setempat menyebut pandhusa, sebutan demikian juga untuk kubur batu yang ditopang batu-batu lain sebagai dinding kubur, banyak ditemukan di Bondowoso (dolmen kubur). Dengan demikian di Bondowoso pandhusa untuk menyebut sarkofagus dan dolmen kubur.

Secara administrasi Sarkofagus Ampelan terdapat di dusun Pandhusa, desa Ampelan, Kecamatan Wringin, Kabupaten Bondowoso. Lokasi tersebut dapat dicapai dengan kendaraan roda empat sejauh $13 \mathrm{Km}$ arah barat laut dari Bondowoso, sampai desa terakhir dan selanjutnya berjalan kaki melalui jalan setapak naik gunung selama 2 jam. Dengan pembacaan GPS (Global Positioning System) lokasi tersebut berada pada $07^{\circ} .49^{\prime} .26,1^{\prime}$ 'Lintang Selatan, dan $113^{\circ} .48^{\prime} .25 .00^{\prime \prime}$ Bujur Timur meredian Jakarta, dan berketinggian 701 meter dari dpal (diatas permukan air laut).

Situs Sarkofagus tersebut berada di sebuah tegalan milik Pak Sahal yang sekaligus menjadi juru pelihara tinggalan di puncak bukit tersebut. Rumah pak Sahal juga berada di tegalan yang mengandung padhusa ini. Luas situs berukuran $40 \times 40$ meter, terdapat 7 buah sarkofagus yang sudah tampak di permukaan tanah. Kemungkinan masih ada yang lain masih terpendam. Sampai saat ini situs tersebut belum pernah dibicarakan, oleh karena itu pada saat ini penulis akan mencoba menyajikan data tentang tinggalan megalitik tersebut.

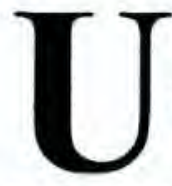

raian temuan

Sebelum membicarakan temuan pada situs megalitik di Pandhusa, Ampelan, Wringin, Bondowoso, akan diuraikan jenis-jenis temuan megalitik di Indonesia. Klasifikasi benda megalitik telah dilakukan oleh Dr A.N.J.Th.A. Th.van der Hoop sebagai berikut: (van der Hoop.1932: 66-149)

1. Stone image (arca batu)

2. Lesung batu (lumpang batu)

3. Upright stone (menhir) 
4. Stone avenues (jalanan batu

5. Tetraliths (kelompok batu empat)

6. Dolmen

7. Stone cist (peti kubur batu)

8. Terrace grave(kubur teras berundak)

9. Pit marked stone (batu dakon)

Apabila jenis temuan dari situs Pandusa, Ampelan, Wringin ini dikaitkan dengan hasil klasifikasi van der Hoop di atas, maka keduanya masuk jenis kubur batu. Bedanya dalam klasifikasi van der Hoop disebut kubur peti batu (stone cist), sedang temuan di Ampelan berbentuk kubur batu yang terdiri dari wadah dan tutup. Masyarakat setempat menyebut pandusa; penyebutan pandusa juga untuk dolmen kubur yaitu kubur batu yang ditopang batu-batu lain sebagai dinding kubur yang banyak ditemukan di Bondowoso.

Frits A. Wagner menyebutkan bahwa pengertian megalitik tidak selalu harus dihubungkan dengan batu-batu besar, karena batasan batu-batu besar tersebut dapat mengarah kepada konsep yang keliru. Monumen dari batu-batu kecil dapat pula dimasukkan dalam klasifikasi megalitik, apabila hal tersebut dimaksudkan untuk tujuan sakral ( Wagner, 1959: 23-24).

Daftar Sarkofagus di dusun Pandusa, Ampelan, Wingin, Bondowoso

\begin{tabular}{|l|l|l|l|l|l|}
\hline \multirow{2}{*}{ No. } & \multirow{2}{*}{ Jenis temuan } & \multicolumn{3}{c|}{ Ukuran (cm) } & \multirow{2}{*}{ Keterangan } \\
\cline { 3 - 5 } & & $\mathrm{P}$ & $\mathrm{L}$ & $\mathrm{T}$ & \\
\hline 1 & Sarkofagus-1 & 90 & 60 & 20 & pecahan \\
\hline 2. & Sarkofagus-2 & 42 & 25 & & Pecah jadi 3 bag. \\
\hline & & 60 & 60 & & \\
\hline & & 90 & 25 & & \\
\hline 3. & Sarkofagus-3 & 230 & 120 & 37 & Wadah dan tutup \\
\hline & & 200 & 105 & 96 & \\
\hline 4. & Sarkofagus (tutup)-4 & 200 & 80 & 40 & \\
\hline 5. & Sarkofagus (wadah)-5 & 230 & 110 & 100 & \\
\hline 6. & Sarkofagus-6 & 60 & 90 & 50 & Tertutup tanah \\
\hline 7. & Sarkofagus-7 (wadah) & 80 & 50 & 65 & \\
\hline
\end{tabular}

Keterangan :

$P$ : panjang

L : lebar

$\mathrm{T}$ : tinggi 
Pengertian umum tentang tradisi megalitik adalah satu tradisi yang pemujaan pemujaan kepada roh nenek moyang (Teguh Asmar, 1974 : 19). Kenyataan tersebut di atas antara lain ditemukan di situs-situs megalitik di Eropa Barat, misalnya Skandinavia dan Inggris bagian selatan (Adamson Hoebel, 1958 : 101-105).

Di Indonesia sering terjadi penyimpangan, antara lain monumen magalitik banyak didirikan tanpa menggunakan batu besar dan bahan yang digunakan tidak selalu batu utuh. Pendirian bangunan megalitik oleh pendukungnya dimaksudkan sebagai upacara ritual. Upacara ritual tersebut selalu bertujuan pemujaan kepada roh nenek moyang. Hal ini antara lain dibuktikan pada penemuan Sarkofagus di dusun Pandusa desa Ampelan Kecamatan Wringin, Kabupaten Bondowoso.. Upacara ritual yang berhubungan dengan Sarkofagus tersebut adalah upacara penguburan.

Penelitian Sarkofagus yang lebih mendalam pernah dilakukan R.P. Soejono terhadap Sarkofagus di Bali (R.P. Soejono, 1977) Substansi penelitian tersebut antara lain :

1. Arti religius dari bentuk-bentuk sarkofagus

2. Tata cara penguburan sarkofagus

3. Arti adat sarkofagus dalam kesenian

4. Masalah asal-usul adat sarkofagus

\section{Arti religius dari bentuk-bentuk sarkofagus.}

Bentuk dasar atau bentuk pokok sakofagus, tanpa kita perhatikan tonjolan atau hiasan lainnya perlu diperhatikan. Beberapa jenis mempunyai bentuk yang mirip dengan perahu. Van Heekeren pernah mengajukan pendapat bahwa sarkofagus mungkin disebarkan oleh orang-orang yang dahulu datang di tempat-tempat penyebaran mereka dengan perahu dan jika meninggal, maka mayat mereka diletakan dalam perahu dan ditempatan di atas panggung. Kelak setelah pindah ke daerah pedalaman mereka membuat peti mayat kayu yang seringkali mirip dengan bentuk perahu serta ditempatkan pula di atas panggung kayu atau landasan lain; bahan kayu ini lambat laun diganti dengan batu. Adat menaruh mayat dalam perahu masih dilakukan oleh beberapa suku bangsa di Indonesia.

Bentuk yang lain menyimpang dari bentuk tersebut. Variasi-variasi bentuk dasar sarkofagus merupakan hasil perkembangan yang telah jauh dari asal mula peristiwaperistiawa migrasi yang lampau, akan tetapi bentuk-bentuk yang mirip perhu membuktikan, bahwa ingatan akan peristiwa penting masa lalu itu masih melekat pada pendukung-pendukung adat sarkofagus.

Bentuk-bentuk semetris yang dipilih untuk sarkofagus itu ialah karena tradisi kebudayaan perunggu, yang antara lain terkenal akan kekayaan pola-pola hiasan 
geometrik, telah meluaskan diri dan menjadi ciri penting untuk masa itu. Corak geometrispun kita dapati pada bentuk sebagian tonjolan sarkofagus seperti misalnya bulat/lingkaran, bujur sangkar/ persegi panjang, segi tujuh dan sebagainya. Tonjolantonjolan yang beraneka warna coraknya itu mempunyai fungsi yang dapat dibedakan fungsi praktis, dekoratif, dan religius.

Tonjolan yang berfungsi praktis adalah tonjolan yang dipahatkan dengan maksud menjadi alat bantuan pada waktu pengangkutan. Dalam golongan ini dapat kita masukan tonjolann-tonjolan tebal khususnya. Korn pernah menyatakan bahwa sebuah tonjolan sarkofagus, mempunyai aluran lebar sebagai bekas tempat tali.

Pada suku bangsa Toraja Barat di Rampi peti mayat kayu dari seorang pemimpin adat diberi tonjolan pada masing-masing sisi ujungnya. Tonjolan ini dimaksudkan sebagai pegangan untuk mengangkat peti. Hal ini dijelaskan oleh Kruyt dalam uraiannya tentang upacara kematian.

Berdasarkan penelitian R.P.Soejono, fungsi praktis dari tonjolan-tonjolan sarkofagus sukar diterima, walaupun corak tonjolannya tebal, polos dan masif karena :

a. Ukuran tonjolan-tonjolan ini jika dibandingkan dengan ukuran seluruh sarkofagus terlalu kecil dan jika dijadikan tempat tali, tonjolan-tonjolan akan patah karena tak kuat menahan seluruh wadah atau tutup sarkofagus.

b. Juga bahan paras yang lembek termasuk faktor yang tidak mengijinkan.

c. Ukuran dan letak tonjolan yang teratur di bagian-bagian tertentu pada wadah/tutup menyatakan, bahwa tonjolan-tonjolan ini sebenarnya tidak dimakdutkan untuk pegangan, akan tetapi untuk maksud lain..

Persoalan tonjolan ini dihadapi pula oleh Willems waktu mengadakan penelitian pandusa di Pakauman (Bondowoso). Dinding samping pandusa juga bertonjolan bundar, yang letaknya tak teratur dan memang digunakan sebagai pegangan untuk mempermudah pengangkutan.

Fungsi dekoratif digambarkan oleh tonjolan-tonjolan pepeng berbentuk lukisan geometrik. Lukisan -lukisan geometris juga ditemukan secara tergores pada sarkofagus Besuki, antara lain di Tanggulangin (lingkaran konsentris, setengah lingkaran, segi tiga sama kaki) dab Kretek (lingkaran, Elips) dan di pulau Sumba secara pahatan bas-relief : lingkaran konsentris, tumpal dan lain-lain (Heekeren, 1958 :47. Selain mempunyai fungsi dekoratif tanda-tanda geometris pada suku-suku bangsa tertentu di beberapa bagian dunia mengandung pula arti-arti sosial, gegrafis atau religius (Boas, 1955).

Fungsi religius dapat kita simpulkan terhadap tonjolan-tonjolan benbentuk kepala atau topeng dan pahatan-pahatan "en- relief" tubuh manusia dengan tonjolan-tonjolan 
berbentuk kepala dan ekor. Tonjolan-tonjolan berbentuk kepala atau topeng dalam berbagai corak mengandung maksud tertentu, yaitu untuk mencegah segala macam kekuatan jahat yang akan mengganggu arwah dalam perjalanannya kalam baka. Muka dan mata manusia menurut kepercayaan universil mengandung kekeuatan gaib terbanyak. Tubuh manusia pun dijadikan motif pahatan, karena badan manusia juga memiliki kekuatan-kekuatan gaib, sehingga bentuknya dipandang sebagai lambang atau wakil roh orang yang meninggal.

\section{Tatacara dalam penguburan dengan sarkofagus}

Penguburan dengan sarkofagus rupa-rupanya diselenggarakan dengan tatacara dan upacara tertentu. Bukti-bukti yang didapat dari penelitian dan ekskavasi memberikan gambaran bagaimana sebagian dari pelaksanaan penguburan itu dilangsungkan. Beberapa contoh sebagai perbandingan, terutama data dari Pulau Sumba yang sampai kini masih meneruskan adat penguburan sarkofagus dan dolmen (Kruyt, 1922: 466609; Buhler 1951: 51-77).

Pada jaman perundagian tidak semua mayat dikubur dalam sarkofagus, khusus golongan terkemuka dalam masyarakat waktu itu dapat mengecap perlakuan istimewa ini, sebab pembuatan sarkofagus dan pengangkatan bahan-bahannya memerlukan tenaga dan waktu yang tidak sedikit. Terutama untuk mempersiapkan tipe-tipe sarkofagus besar dan sedang diperlukan pengerahan tenaga manusia.

Sebuah contoh masa kini tentang penguburan golongan pemimpin dalam peti kita temukan di Timor. Di sini hanya keluarga golongan usif yaitu memimpin masyarakat, dikubur dalam peti kayu (Kruyt 1923 387). Di Sumba Barat oleh Kecrs digambarkan betapa besar tenaga yang dipersiapkan untuk mengangkut batu-batu besar yang akan digunakan membuat kubur batu.

Penguburan tanpa sarkofagus yang diduga dari jaman yang sama ditemukan oleh Korn di sekitar sarkofagus-sarkofagus di Bali tahun 1930, kemudian oleh penduduk pada tahun 1958 berturut-turut dilaporkan penemuan-penemuan sejumlah benda-benda perunggu dengan sisa-sisa tulang manusia. Pada tahun 1960 dilaporkan tentang temuan sebuah rangka terletak membujur didekat sarkofagus dan pada tahun itu juga sisa rangka dengan dua buah gelang perunggu berukuran besar ditemukan di Ubud, Bali. Ini semua cukup membuktikan bahwa hanya golongan-golongan tertentu terutama golongan pemimpin masyarakat yang berpengaruh, melaksanakan penguburan sarkofagus (Heekeren 1941: 14; 1955: 14).

Yang dikubur dalam sarkofagus di Bali adalah orang-orang dewasa dan anak-anak. Penguburan anak-anak dalam sikap terlipat dibuktikan oleh sarkofagus ukuran kecil serta berongga sempit. Van Heekeren menjumpai pula sarkofagus ukuran kecil di Besuki, yang diduga sebagai tempat mengubur nanak-anak (Heekeren, 194I: 9). Sampai sekarang baik di Besuki maupun di Bali, belum diternukan bukti-bukti nyata 
berupa rangka anak-nanak dalam sarkofagus, tetapi kebiasaan semacam ini masih terdapat di Sumba, dimana nanak-nank ditanam dalam sarkofagus bersma-sama dengan orang tuanya.

Penempatan dalam sarkofagus yang umum ialah dalam sikap terlipat. Mengenai sikap ini hanya ada beberapa bukti yang dapat didokumentasikan dalam foto dan masingmasing menunjukan detail yang berlainan. Bukti pertama dijumpai Van Stein Callenfels pada tahun 1931 di Angantiga, Bali. Disini mayat tampak dalam sikap terlipat lateral miring ke kiri. Bukti ke dua ditemukan di Cacang Bali oleh RP Soejono dalam sebuah ekskavasi tahun 1960. Mayatnya terdapat dalam sikap terlipat dorsal dengan badan dan muka menghadap ke atas. Pada sikap lateral, lutut ditarik ke atas sampai pinggang, lengan bawah di sejajarkan dengan paha dan kepala agak merunduk, sedangkan sikap dorsal tungkai dilipat sampai dagu, ke dua tangan menyilang di dada dan kepala tunduk.

Sikap terlipat menurut R.P Soejono mengandung maksud memberi sikap kepada mayat seakan-kan si mati dalam keadaan siap untuk lahir kembali didalam suatu kehidupan baru. Sikap terlipat yang diterapkan pada mayat ini kita jumpai pada berbagai suku bangsa di Indonesia Timur (antara lain Alfuru, Sumba, Aru,Kei) dan Irian Jaya (R.P. Soejono $1977: 146$ ).

\section{Arti adat sarkofagus dalam kesenian}

Di bidang kesenian, khusus seni pahat, seni menuang perunggu dan seni gerabah, tampak suatu kegiatan yang telah meningkat pada jaman itu. Kebiasaan mempergunakan batu padas di Bali dan Bondowoso dewasa ini untuk mendirikan bangunan atau untuk memahat benda-benda lain, sebenarnya telah berkembang pada jaman pembuatan sarkofagus ini. Sarkofagus-sarkofagus tipe kecil atau tipe sedang sebenarnya di pahat dari batu padas, kecuali di tempat-tempat yang tidak ada bahan tersebut.

Walau pun terdapat gaya-gaya tersendiri di daerah-daerah tertentu, namun pemahatpemahat terikat oleh unsur-unsur formal yang menghendaki keseragaman (misalnya tutup dan wadah harus sama dam sebangun dan lain sebagainya) dan oleh cita-cita religius yang bertujuan memberikan kelangsungan kehidupan kepada arwah leluhur serta memuja arwah leluhur untuk mohon perlindungan mereka.

Contoh yang menarik, bahwa ikatan tadi tetap berkuasa ialah pada corak tonjolan kepala. Raut muka menunjukan variasi-variasi dari pancaran yang kaku. Sampai ke pancaran yang penuh ekpresi.

Unsur formal di atas, disertai dengan penguasaan teknik pemahatan dan kemudian dibubui dengan variasi-varisi pada bentuk mulut (tersenyum, menganga, mengeluarkan lidah, melawak dengan bibir) yang disesuaikan dengan perasaan para 
pemahat, telah meciptakan buah pahatan yang mengandung nilai seni yang tinggi (artistic value). Keleluasaan dalam mengutarakan seni semacam ini telah menjadi dasar seni pahat di kemudian hari (sekarang).

Suatu hal yang patut dikemukakan ialah, bahwa pahatan tonjolan kepala dengan muka melawak adalah sebenarnya bentuk proto tipe tokoh-tokoh Merdah, Twalen cs (atau Semar cs di Jawa). Kesaktian tokoh-tokoh tersebut yang selama ini dipandang sebagai "survival" dewa-dewa Indonesia aseli, dapat pula disimpulkan terhadap tonjolantonjolan bentuk kepala (atau kedok) pada beberapa sarkofagus. Dengan contoh ini dapatlah di duga, bahwa tokoh-tokh pelawak sakti yang terkenal dalam cerita-cerita kepercayaan beberapa suku bangsa (khususnya di Jawa dan Bali), pada fase pertamanya adalah arwah seorang berkuasa, yang penuh kekuatan gaib dan dengan kesaktiannya ini menjadi pelindung umat dan masyarakatnya.

Bentuk manusia dalam sikap kangkang seperti yang sering terlihat pada sarkofagussarkofagus, mempunyai kelanjutan pada seni pahat di masa kemudian. Dalam seni pahat di Bali terdapat sebuah bentuk yang dikenal dengan buta sungsang (kala sungsang). Buta sungsang tergolong makhluk yang mendiami dunia bawah (inferno) atau dunia kematian, sehingga bentuk hiasan ini ditemukan umumnya di pura dalem yang berhubungan dengan dunia kematian dalam sistem kepercayaan di Bali..

Penampilan tokoh-tokoh buta sungsang dan tokoh bersikap kang-kang pada pura-pura di Bali ini menurut RP Soejono menunjuk ke suatu latar belakang kepercayaan, bahwa arwah orang-orang yang meninggal, di dunia kematian harus dilindungi terhadap kekuatan-kekuatan jahat yang dapat mengganggu.

Pada jaman sarkofagus ini masyarakat telah memiliki kemampuan menuang barangbarang perunggu. Hal ini dapat dibuktikan dengan temuan fragmen-fragmen cetaan batu untuk menuang perunggu (antara lain nekara dan bermacam-macam perhiasan atau benda-benda upacara)(BernetKempers, 1956).

Seni gerabah pada jaman ini tidak menunjukan hasil-hasil yang berarti. Barang-barang gerabah kebanyakan ditemukan berupa fragmen, berwarna kemerahan pada umumnya polos. Gerabah dengan pola hias

\section{Masalah asal-usul adat sarkofagus.}

Sarkofagus-sarkofagus di Jawa dan Bali di samping memberikan bahan untuk mengetahui adat istiadat dan cita-cita religius pada masa lalu, membawakan pula masalah-masalah yang masih harus dicari penyelesaiannya.

Jaman pembuatan sarkofagus seperti telah ditetapkan oleh Van Stein Callenfels dan Van Heekeren jatuh pada masa perkembangan kebudayaan perunggu yaitu pada jaman perundagian di Indonesia. Pada jaman ini mulai dikenal pula pembuatan benda- 
benda besi seperti antara lain telah dibuktikan oleh penemuan-penemuan dalam sarkofagus.

Penetapan masa perkembangan ini diperkuat dengan bukti-bukti lain, yaitu corak tonjolan bentuk kepala, raut muka tonjolan sarkofagus, dengan telinganya yang panjang, mirip sekali dengan corak hiasan kedok nekara perunggu

Demikian, maka sarkofagus di Ampelan Wringin, Bondowoso mempunyai latar belakang dan sekaligus merupakan cerminan budaya seperti yang terurai di atas..

\section{KEPUSTAKAAN}

Buhler, A. 1951 "Bemerkungen zur Kulturgeschichte Sumbas." Sudseestudien. Basel : $51-76$

Fritz A. Wagner. 1959. "Indonesia The Art of an Island Group" Art of the World Series. Methuen, Londen

Heekeren, H.R. van 1931. "Megalithische overblijfselen in Besoeki Java" DJAWA, XI. : $1-18$ ,1955, "Proto-historic sarcophagi on Bali". Bulletin of the Archaeological Servise of the Republic of Indonesia. Jakarta, Archaeological Service of Indonesia, No. II : 1-15

Hoop, A.N.J. van der. 1932. Megalithic Remains in South Sumatra. Zutphen W.J Thieme \& Oie Translated by William Shirlaw .

Keers,W.C 1938."Indrukken van het megalithische tijperk van West Sumba"Tijdschrift van het Koninl;iij Nederland Aardrijskundige Genootschap, Amsterdam, Utrecht, Leiden.

Kruyt, Albert C. 1922 "Soembaneezen." BKI, LXXVIII : 466-608

Soejono, R.P. 1977. Sistim-Sistim Penguburan Pada Akhir Masa Prasejarah Di Bali. Desertasi. Universitas Indonesi 1976. Sejarah Nasional Indonesia I, Jakarta, Balai Pustaka

Stein Callenfels, P.V. van. 1931. "Merkwaardige vonsten op Bali. De Cultuur vanhet Bronstijperk."Java Bode, No.108, 80ste jg 
Teguh Asmar. " Pengetahuan masa kini tentng Peasejarah Sulawesi Utara, Bulletin Yaperna, Th I No. 1 